TEACHING TACTIC

\title{
Zoom in on Interpretive Skills
}

Amy Beth Jones

Independent Scholar

Stephanie Day Powell
Manhattan College

The context

We created this twenty- to forty-minute exercise for first-year students in a biblical exegetical skills course at Drew University Theological School, though it could be used in any context where students are expected to read texts closely and critically. If one does not have access to the picture book, Zoom, the exercise can be reproduced using any two images that compare a long shot to a closeup of the same image.

\section{The pedagogical purpose}

To (1) concretize many theoretical lessons about exegesis, from the importance of the contextual translation of words to the necessity to read in community rather than in isolation, and (2) impress upon students the need to read texts in their larger literary, historical, social, and theological contexts.

\section{Description of the strategy}

Each page of Istvan Banyai's evocative picture book, Zoom (Viking, 1995), is an inset of the drawing on the page that follows (see sample here ${ }^{1}$ ). With every page, one must zoom out to discover a fuller or more detailed picture - a useful analogy for the play of perspectives involved in any sustained literary inquiry.

Distributing illustrations from Zoom, we divide the class into groups, telling them that they are each receiving "identical” images. The groups discuss their images and produce a paragraph describing their scene. When the class reconvenes, each group shares their description and soon they realize that their images are (seemingly) different from one another. Then they begin to recognize the connection between scenes, and a conversation about experience and vantage point ensues.

We employed Zoom alongside a study of Genesis 16 in order to challenge hackneyed interpretations of Abraham's character. After this activity, students read the story of Hagar and Sarai twice, first as an individual story and then within the larger Abrahamic cycle. While they initially viewed Abraham as the spiritual hero, they soon redirected their attention to how his misogyny is at odds with his ostensible faith. They then rezoomed to more substantively analyze the patriarchal context in which the female protagonists struggle for representation. The lessons of Zoom stayed with them as they widened their field of vision beyond Genesis to reflect upon the greater Deuteronomistic narrative of human failings and unfinished redemption.

\section{Why it is effective}

While one student group produces a narrative about a cityscape, another produces a story about a lone cowboy in the desert watching a television show set in the city. Students come to realize that the cityscape is merely an inset within the larger desert image. The exercise disorients students and gives them a tangible example of the focalized nature and limits of their perspectives. As students continually zoom and rezoom on the interpretive landscape, superficial readings are rejected for multilayered analyses that replicate the complexities of critical interpretation.

1 https://www.wabashcenter.wabash.edu/wp-content/uploads/2019/11/Jones_And_Powell_TACTIC-Zoom-Photos.jpeg (accessed 14 August 2019). 